Article

\title{
Application of HYSPLIT and WRF/Chem Models to Investigate the Dust Storm Episodes
}

\author{
Parya Broomandi ${ }^{1}$, Bahram Dabir ${ }^{1}$, Babak Bonakdarpour ${ }^{1}$ and Yousef Rashidi 2, * \\ ${ }^{1}$ Department of Chemical Engineering, Amirkabir University of Technology, Tehran 15875-4413, Iran; \\ paryabroomandi@gmail.com (P.B.); drbdabir@aut.ac.ir (B.D.); babakb@aut.ac.ir (B.B.) \\ 2 Environmental Sciences Research Institute, Shahid Beheshti University, Tehran 1983963113, Iran; \\ * Correspondence: y_rashidi@sbu.ac.ir; Tel.: +98 212243 1971, Fax: +98 212243197
}

\begin{abstract}
Background: Long-range transport of dust aerosol has intense impacts on the atmospheric environment over wide areas. Methods: The annual and seasonal changes in meteorological parameters associated with the occurrence of dust storms were studied. The features of an intense dust storm and its transport characteristics were studied during June $7^{\text {th }}$ to June $9^{\text {th }} 2010$ in Ahvaz city. Temporal and spatial distribution of Middle Eastern dust storm event was analyzed by models of HYSPLIT and WRF/Chem, and in- situ observations. Results: A disagreement between the occurrences of dust storms, temperature, relative humidity and rainfall, show the major source of dust storms over Ahvaz city are neighboring countries. Using HYSPLIT results, the dust particles are mainly transported from north western region of Iraq and eastern Syria to downward areas including Ahvaz city. The arrived Dust aerosols mixed with local anthropogenic emissions, led to the highest PM10 concentration of $4200 \mathrm{ppm}$. The model results were found to well reproduce temporal and spatial distribution of mineral dust concentrations according to in-situ measurements. Conclusion: The performance of WRF/Chem was acceptable for simulation of temporal and spatial distributions of dust storm events. Therefore, it can be taken as a reference in daily air quality forecasting.
\end{abstract}

Keywords: particulate matter; dust storm; meteorological parameter; HYSPLIT; WRF/Chem

\section{Introduction}

Dust storms mostly happen throughout the desert regions of the world, specifically during springtime. The large amount of dust particles are injected into the atmosphere from deserts. Dust aerosols have a wide range of impacts on global climate, ambient air quality, atmospheric biogeochemical mechanisms [1,2]. Dust particles are able to disturb the radiation budget of earth directly by interacting with both short- and long wave radiation and by changing the optical properties of cloud and microphysics of cloud indirectly [3]. Dust aerosols influence the chemistry wide areas by deposition of different trace elements [4,5], and alter terrestrial and oceanic biogeochemistry by transporting nutrients like iron [6]. Dust aerosols can affect rainfall and cloud properties due to their potential ability in cloud condensation nuclei and ice nuclei $[7,8]$. Through radiative effects, dust particles are able also to impact the atmospheric dynamics [4]. In general, particles are ejected from the arid and desert areas around the world with about $90 \%$ of the total emissions happening mainly in northern Africa in the Northern Hemisphere [9]. The global total 
dust emissions throughout global models with highly uncertainty, range from 500 to $6000{\mathrm{Tg} \mathrm{yr}^{-1}}^{-1}$ $[10,11]$. The wet and dry deposition are responsible mechanisms for removing dust aerosols from the atmosphere. The wet deposition is dominated during long-range transport over the oceanic regions but dry deposition remove the larger particles near the source areas. The most high risk city of Iran namely Ahvaz, the capital of Khuzestan province of Iran, is close to Iraq, Syria, Saudi Arabia and Kuwait, which are main dust sources in this area. This city is widely influenced by mineral which are carried by a hot dominant northwesterly wind during the spring, Shimali wind, which is able to carry a large amount of dust particles from southern parts of Iraq [12]. Specially, Iraq should be a great source of concerns, with extensive areas of sand desert (nearly $40 \%$ of the country's total area). The severe drought of 1999, deforestation actions, inappropriate land use, war impacts, unstable political situation and lack of appropriate internal decision-making have increased the rate of desertification in this country [12]. There are different developed techniques to locate dust hotspots and trajectories. The analysis of particle trajectory, numerical simulation, analysis of dust observation and meteorological information, Satellite imagery and Remote sensing method, mineral detectors and geological models are the main tools to investigate the dust storm events [13, 14]. A few studies have been conducted to identify dust sources, trajectories, contribution of dust particles to urban PM10 concentrations and spatial and temporal coverage of dust by using modeling techniques in Iran. The satellite images and meteorological data analysis were used frequently in most of the conducted studies on these issues [13]. Using the WHO database, Ahvaz is the first polluted city in the world, with the annual average particulate matter concentration of $372 \mu \mathrm{g} / \mathrm{m}^{3}$ [15]. Identifying the dust hotspots and pathways which lead to the dust storm events in Iran, has a considerable importance. The dust storm simulation is important not only for locating its sources, formation, dust diffusion and transportation and deposition but also for management and of its environmental dangers. In this study we investigated the relationship between dust storm frequencies and meteorological parameters. Then the temporal and spatial distribution of mineral dust were simulated with HYSPLIT (version 4) model and WRF/Chem (version 3.5) model. The modeled results were evaluated with in- situ PM10 measurements during June $7^{\text {th }}$ to June $9^{\text {th }} 2010$ in Ahvaz city. At last, the results can be used to decrease and control the level of dust particles.

\section{Material and Methods}

\subsection{Base case study}

The study area, Ahvaz city, which is located at $48^{\circ} 40^{\prime}$ longitude and $30^{\circ} 20^{\prime}$ latitude, was chosen to study the air quality modeling in June 2010. It occupies $8152 \mathrm{~km}^{2}$ in southwestern Iran with inhabitants during the studied period. Its climate varies from arid to humid. Warm period is from April to September, while cold period is from October to March. Data taken from Ahvaz metrological station, which records the climatic elements such as maximum and minimum of temperature, rainfall, relative humidity, wind speed and direction and dust storm frequencies of the dust storm occurrence) [16]. The annual average of maximum temperature in warm period was about $47^{\circ} \mathrm{C}$ (in July) and minimum temperature in cold period was about $8^{\circ} \mathrm{C}$ (in March). The annual mean rainfall amount was $173.4 \mathrm{~mm}$ with the maximum amount of $85 \mathrm{~mm}$ in March. Also, 
annual evaporation was about $3097 \mathrm{~mm}$. Ahvaz city is influenced by southwestern winds at the North.

\subsection{Numerical Models}

\subsubsection{HYSPLIT Model}

In order to analyze the origins and trajectory of dust aerosols, Online HYSPLIT.4 ((HYbrid Single-Particle Lagrangian Integrated Trajectory) model was used with $1^{\circ} \times 1^{\circ}$ resolution meteorological data [17]. HYSPLIT includes three types of trajectories, which can be computed: Normal, Matrix, and Ensemble. The pathways from a matrix distribution of locations of an area are computed using Matrix trajectory, but multiple pathways from one position by all-possible deviations in $\mathrm{X}, \mathrm{Y}$, and $\mathrm{Z}$ are calculated using Ensemble trajectory. The meteorological field resolution can cause uncertainty in the modeling. In order to reduce the model uncertainty, Ensemble trajectory is used to compute the all possible pathways.

\subsubsection{WRF/Chem Model}

WRF/Chem (Weather Research and Forecasting/Chemistry model) version 3.5 was used to model the outbreak and transport process of dust and its impact on Ahvaz city air quality with 1 nested domain. It is one of the currently used models to investigate the air quality and dust problems. It is a coupled meteorology-chemistry community model (WRF/Chem), which is developed by NOAA and other research institutions. It is can be used in a simulation of the chemistry, dust and aerosols from local to global scales. The chemical and meteorological sub-models are completely online coupled. They are using the identical horizontal and vertical coordinates and the identical physical options. There is not any temporal interpolation. Also, there are feedbacks between the chemical and physical interactions [18]. The chemical sub-model is consist of both chemical and physical processes. It contains the convective and advective transport of chemical; biogenic and anthropogenic emissions; wet and dry depositions; aqueous and gas phase modules; photolysis; dynamics of aerosol and chemistry beside the indirect and direct impacts of aerosol. Commonly, it can be used in a wide spectrum of applications with scales ranging from meters to thousands of kilometers. Real- time forecasting and modeling tests have illustrated that the good performance of WRF model in weather forecasting [19, 20]. This model allows the use of dust modules developed by the GOCART model (Georgia Tech/Goddard Global Ozone Chemistry Aerosol Radiation and Transport model). Also, it is capable of prediction the dust transport along with the meteorology by considering dust erosion areas which are taken from GOCART dust emission [21, 22]. The GOCART calculate the dust emission for each dust particle size considering the soil erosion factor, particle fraction, surface wind speed and the threshold wind speed of wind erosion. The dust particle sizes include 5 size bins in the WRF / Chem model the, with a mean radius of 0.6, 1.2, 2.4, 4.5 , and $8.0 \mu \mathrm{m}$, respectively. The flux $\mathrm{F}_{\mathrm{p}}$ of particle size class $\mathrm{p}$ is approximately calculated by the

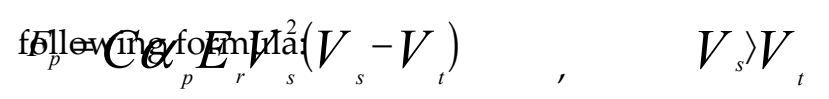

$F_{P}=0$

Otherwise 
4 of 18

Where $\mathrm{C}$ is a dimensional factor equal to $0.8 \mu \mathrm{g} . \mathrm{m}^{2} . \mathrm{s}^{-5}, \alpha_{\mathrm{p}}$ is the soil particle fraction of size bin $\mathrm{p}, \mathrm{Er}$ is the probability soil erosion factor, $V_{s}$ is the wind velocity at $10 \mathrm{~m}$, and $\mathrm{V}_{\mathrm{t}}$ is the threshold velocity of wind erosion. The threshold velocity is computed as a function of the, particle size, density, and the moisture content of soil [21, 23]. The configuration of modeling and designed domain in this study is shown Table 1. WRF/Chem version 3.5 allows the use both of MODIS (Moderate Resolution Imaging Spectroradiometer) and USGS (U.S. Geological Survey) land use. In Ahvaz with complex topography USGS with 24 categories and 30s resolution is used. For diagnostic analysis and initial and boundary conditions of the model, 6-hourly Final (FNL) Operational Global Analysis data with a $1^{\circ} \times 1^{\circ}$ resolution from the National Center for Environmental Prediction (NCEP) were used.

\begin{tabular}{|c|c|}
\hline Process & Values and Options \\
\hline Horizontal grid $(x, y)$ & 300,200 \\
\hline Grid spacing & $10,000 \mathrm{~m}$ \\
\hline Land-use dataset & USGS-24 \\
\hline Meteorological data & FNL \\
\hline Microphysics & WSM 5-class scheme \\
\hline Surface layer & $\begin{array}{l}\text { MM5 Monin-Obukhov } \\
\text { scheme }\end{array}$ \\
\hline Land surface model & $\begin{array}{l}\text { Unified Noah land-surface } \\
\text { model }\end{array}$ \\
\hline Boundary layer & YSU scheme \\
\hline Cumulus option & New Grell scheme (G3) \\
\hline Number of soil layers & Noah land-surface model \\
\hline Chemistry option & Dust 5 size bins \\
\hline Emission option & $\begin{array}{l}\text { MOZCART (MOZART + } \\
\text { GOCART aerosols) emissions }\end{array}$ \\
\hline Dry deposition & $\begin{array}{l}\text { includes dry deposition of } \\
\text { aerosols }\end{array}$ \\
\hline Dust option & $\begin{array}{l}\text { Include GOCART dust } \\
\text { emissions with AFWA } \\
\text { modifications }\end{array}$ \\
\hline
\end{tabular}

Table. 1. WRF/Chem model setup, used in this study. 
In order to evaluate the simulation of meteorological parameters in the WRF/Chem model, several statistical functions were used collectively in the assessment. The following functions are chosen for evaluation in this study: mean absolute error, root mean square error, bias and index of agreement. Mean Absolute Error $(M A E)$ :

$M A E=\sum_{i=1}^{N} \frac{|M i-O i|}{N}$

Where, $O_{i}$ is the observed value of the cell $\mathrm{i}, M_{i}$ is the modeled value of the cell $\mathrm{i}$, and $N$ is the number of values analyzed.

Root Mean Square Error (RMSE) which is the same as MAE but more susceptible to occasional large errors because of its quadratic term:

$R M S E=\sqrt{\sum_{i=1}^{N} \frac{|M i-O i|^{2}}{N}}$

Bias $(B I A S)$ is representing the trend of the model information to overestimate or underestimate a variable, calculates the model systematic error. Pielke (1984) defines BIAS as:

$$
B I A S=\sum_{i=1}^{N} \frac{(M i-O i)}{N}
$$

Index of Agreement (IoA) is representing more understanding of the model behavior for scalar magnitudes. It varies from 0 to $1,(0<I o A<1)$ and is determined by:

$$
I O A=1-\frac{\sum_{i=1}^{N}(M i-O i)^{2}}{\sum_{i=1}^{N}\left(\left|M_{i}-M_{\text {mean }}\right|+\left|O_{i}-O_{\text {mean }}\right|\right)^{2}}
$$

Where $M_{\text {mean }}$ is the mean modeled value and $O_{\text {mean }}$ is the mean observed value.

\section{Results}

\subsection{Meteorological Parameter Analysis}

\subsubsection{Annual variation of Dusty Days and Meteorological Parameters in Ahvaz city}

Fig. 1 is an illustration of dusty days in Ahvaz city over a 20 year period [16]. We can separate dusty days from other regular days, when the PM10 concentration reaches its threshold $\left(100 \mu \mathrm{g} / \mathrm{m}^{3}\right)$ [14]. The number of dusty days has followed a downward trend from 1995 to 2000. As, it dropped to 12 days per year in 1998. After 1999 it experienced a dramatic increase. While it reached to 108 days per year in 2003. A downward trend of dusty days was observed from 2003 to 2009, but the number of dusty days over these years was higher than the years 1995 to 2000. It reached to the value of 160 days per year in 2009, which was the highest value during the studied 20 years. The annual average of meteorological parameters are shown in Fig. 2 in Ahvaz city during 20 year period. The relative humidity and maximum temperature experienced a modest change in these years, which is in stark contrast to the drastic observed changes in the number of the dusty days. Also, the amount of rainfall has experienced more changes than the two other parameters. It should be noted that the lowest amount of rainfall was recorded in the year in which the highest number of dusty days occurred. Using the recorded meteorological parameters, the average prevail wind direction was 
$245^{\circ}$ in 2010, which is representing the common origin of dust storms are Iraq and Saudi Arabia in Ahvaz city [24]. The average recorded prevail wind speed was $11 \mathrm{~m} / \mathrm{sec}$.

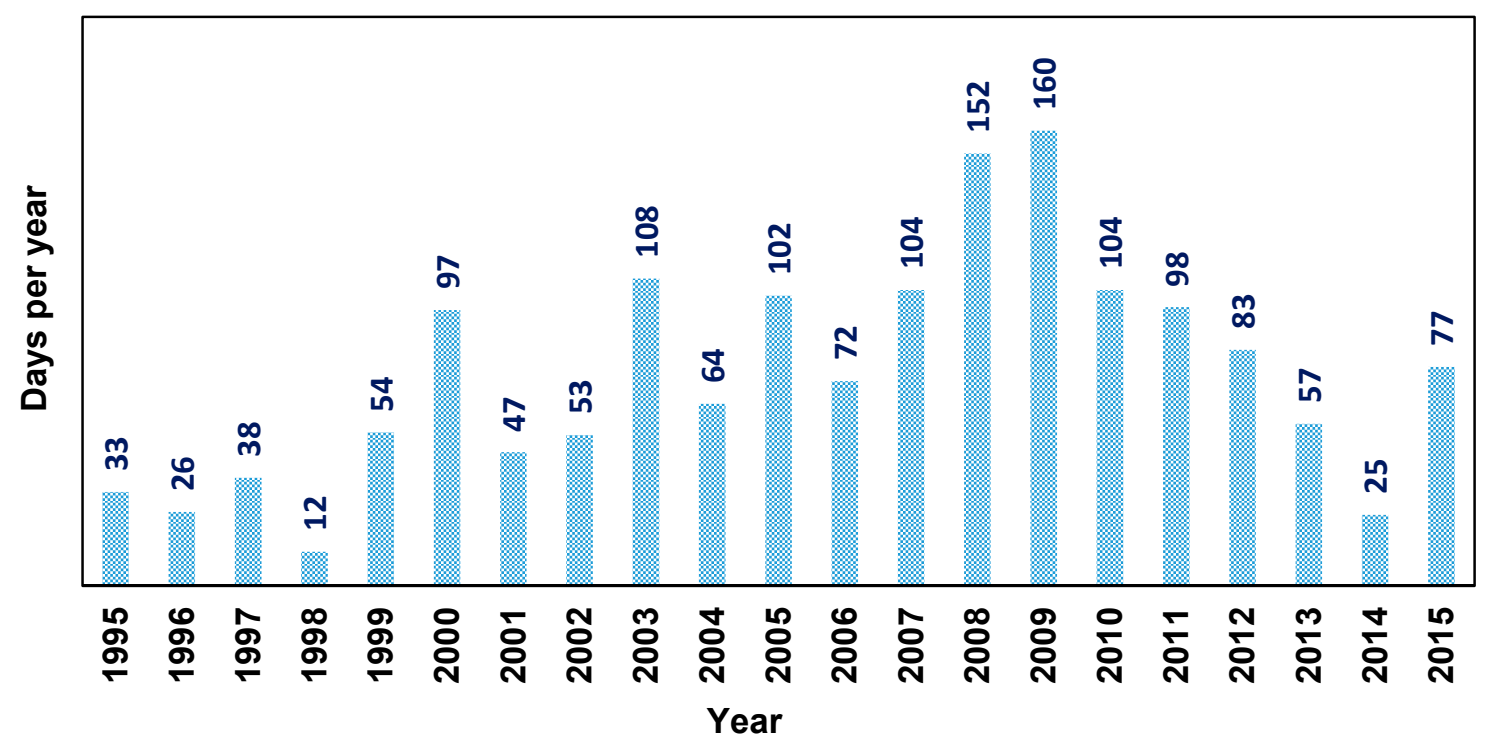

Fig. 1. Number of dusty days over the 20 year period in the city of Ahvaz.

\subsubsection{Seasonal variation of Dusty Days and Meteorological Parameters in Ahvaz city}

Studying the seasonal distribution of dusty days indicated that the maximum number of dusty days was recorded in spring. The value of dusty days reached to 42 days in spring. While it experienced its lowest level of 5 days in fall (in 2010). The seasonal studying of meteorological parameters illustrated that the highest value of relative humidity content was observed in winter, which is not in common with the season with the lowest number of dusty days (fall). Also, the maximum temperature experienced its highest value and the precipitation its lowest amount in summer, whereas, the highest number of dusty days was recorded in spring. The average of dominant wind direction for four seasons; spring, summer, fall and winter were respectively $310^{\circ}, 260^{\circ}, 220^{\circ}$ and $190^{\circ}$. As can be seen, southern to western winds are the prevailing winds in Ahvaz over the studied period. In addition, the average prevail wind speed of $14 \mathrm{~m} / \mathrm{sec}$ was recorded in spring in Ahvaz, which is in agreement with season of the highest number of dusty days.

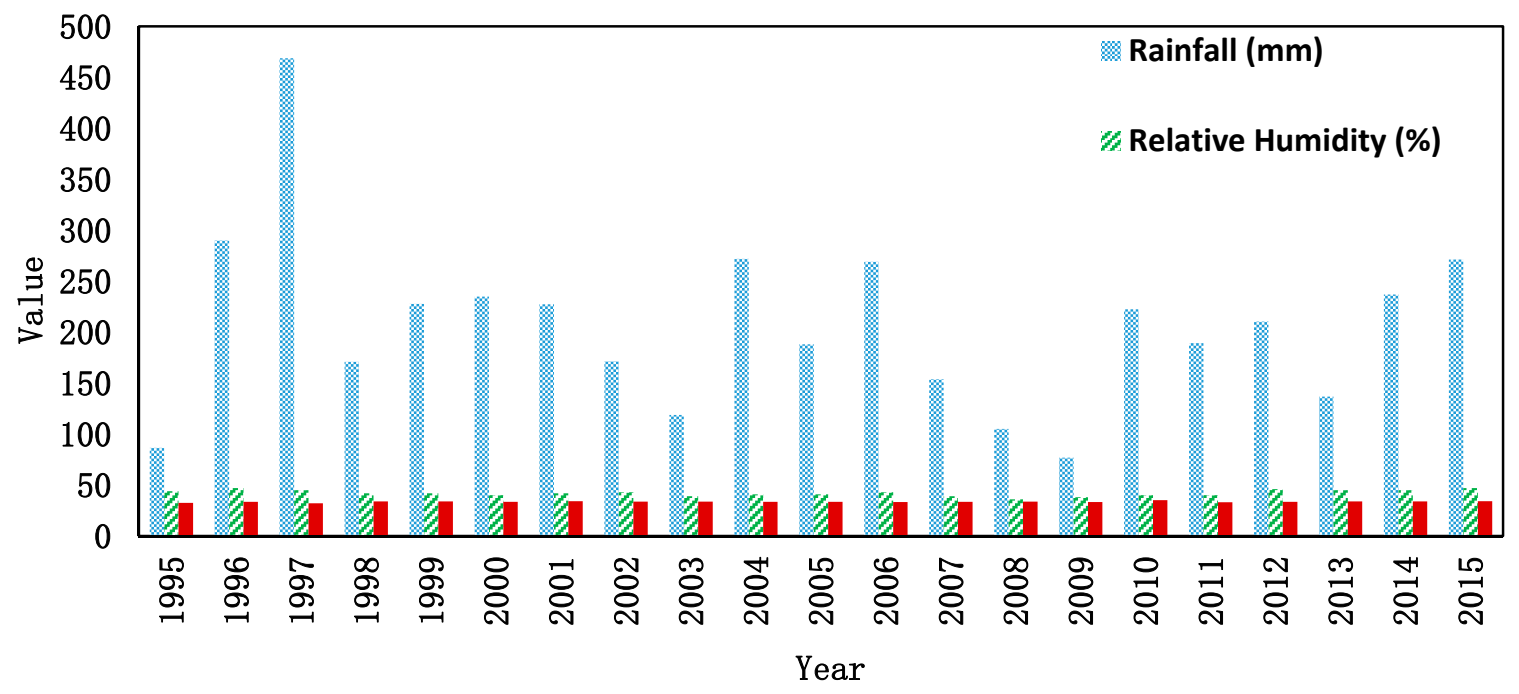


7 of 18

Fig. 2. The annual average Relative Humidity $(\%)$, Maximum Temperature $\left({ }^{\circ} \mathrm{C}\right)$ and rainfall $(\mathrm{mm})$ in Ahvaz station during the studied 20 years.

\subsection{Meteorological simulations}

Statistical analysis, using the observed data for determining the model uncertainty is the most usual method. In this paper, a cell- point procedure has been used to verify the WRF resultants [24]. The model results were compared with observed meteorological parameters. Four meteorological parameters were selected for WRF model verification in this comparison: surface temperature at 2 $\mathrm{m}$ and humidity at $2 \mathrm{~m}$, wind speed and wind direction at $10 \mathrm{~m}$. The wind speed and wind direction were approximated from U10 and V10 wind vector components calculated by the WRF. Also, the humidity was determined using absolute water mixing ratios were derived from relative humidity, temperature and ground-level pressure values. BIAS and IoA were applied for temperature, humidity, and wind speed and wind direction. Although there is much uncertainty in this area, for verification of the model performance, the reference values were chosen after Borge et al., (2008). These reference values should not be considered as if they are certain numbers. The performance measures can change linked to the situation [27]. The model results were compared with Ahvaz meteorological station (48.74 $\mathrm{N}$ and $31.34 \mathrm{E}$ ) observations in Ahvaz city. The comparison of modeled and observed wind speed, wind direction, temperature, humidity are shown in Fig. 3. The statistical results are provided in Table. 2 representing the model's ability in reasonably well, reproducing the observations in the studied area. The correlation factor shows that the WRF model capability in capturing the temporal variation. Comparing the results of statistical parameters with reference values in Table. 2 , the low biases of $1.2{ }^{\circ} \mathrm{C}, 2.59 \mathrm{~m} / \mathrm{sec}, 0.01 \mathrm{~g} / \mathrm{kg}$, and $-30.58^{\circ}$ and the high index of agreement (IOA) values of 1, 0.82 and 0.8 for temperature, wind speed and humidity, respectively, show that the WRF model results reproduced fairly well meteorological parameters. For the wind direction, the difference between the observed and model resultant vector is below $30^{\circ}$, showing the good ability of the model in reproducing the wind direction. As the meteorological parameters have a vital role on regional air quality modeling, it is necessary to select the optimal setup of the meteorological model for air quality integrated assessment simulation. Therefore, further investigations are required to extensive sensitive analysis of the Weather Research Forecasting (WRF) model in the framework of the integrated assessment simulation system for the studied area [26].

\subsection{HYSPLIT Model Implementation}

The HYSPLIT model was used to investigate the backward trajectory of the dust dispersion over Ahvaz city (31, $31 \mathrm{~N}$ and 48, 65 E), Khozestan province, from June $7^{\text {th }}$ to June 9th 2010. The dispersion pathways of dust grains were tracked through $6 \mathrm{~h}$ time intervals up to $24 \mathrm{~h}$ before dust particles reaching the station in atmospheric heights of $500 \mathrm{~m}$. In fact, the wind direction was estimated $24 \mathrm{~h}$ before the dust storm reaching the station. The main reason for this elevation, was tracing the path of the first dust particles one day before occurring in the western borders.

Table. 2. Reference values for verification of WRF model performance after Borge et al., (2008). 
8 of 18

\begin{tabular}{ccccc}
\hline Statistical parameters & $\begin{array}{c}\text { Wind } \\
\text { speed } \\
(\mathrm{m} / \mathrm{sec})\end{array}$ & $\begin{array}{c}\text { Wind } \\
\text { direction }\left({ }^{\circ}\right)\end{array}$ & $\begin{array}{c}\text { Temperature } \\
\text { at } 2 \mathrm{~m}\left({ }^{\circ} \mathrm{c}\right)\end{array}$ & $\begin{array}{c}\text { Humidity } \\
(\mathrm{g} / \mathrm{kg})\end{array}$ \\
\hline $\mathbf{R}$ & --- & --- & -- \\
MAE & 2.8 & 15.4 & 1.84 & 0.06 \\
RMSE & 3.61 & 83.55 & 2.6 & --- \\
BIAS & -2.59 & -30.58 & 1.2 & 0.01 \\
IOA & 0.82 & ---8 & 1 & 0.8 \\
\hline
\end{tabular}

Also, the particles in the height $\leq 500 \mathrm{~m}$ are relatively coarse as well as heavy grains, which can alter the horizontal visibility effectively. Fig. 4 indicated that they are two main paths for transferring the dust to the country: (a) NW- SE direction (the dust particles are transported from the northwestern region of Iraq and eastern Syria), (b) W- E direction (the dust particles are transported from central regions of Iraq to the southwestern and western parts of Iran). According to the results, the NW- SE is the main path for transporting the dust particles to Ahvaz city. Which led to reduction of horizontal visibility under $1000 \mathrm{~m}$ in Ahvaz city [25]. The second route is less abundant than the first path. As can be seen in Fig. 4 the dust particles has followed the same path from NW- SE to Ahvaz city.

\subsection{WRF/CHEM Model Implementation}

The air quality stations, record hourly pollutant concentrations, including PM10 in Ahvaz city. The recorded data from Daneshgah square station $(31,31 \mathrm{~N}$ and 48, $65 \mathrm{E})$ were used in this study. Fig. 5 illustrated the time series of observed and modeled hourly PM10 in Ahvaz city from June $7^{\text {th }}$ to June $9^{\text {th }}$ 2010. The order of magnitude of modeled maximum of PM10 is well agreed with that of observation in Ahvaz city and the peaks of dust particles are obviously represented. 


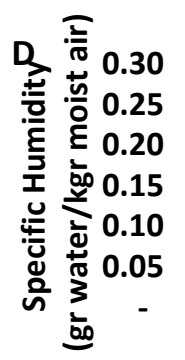
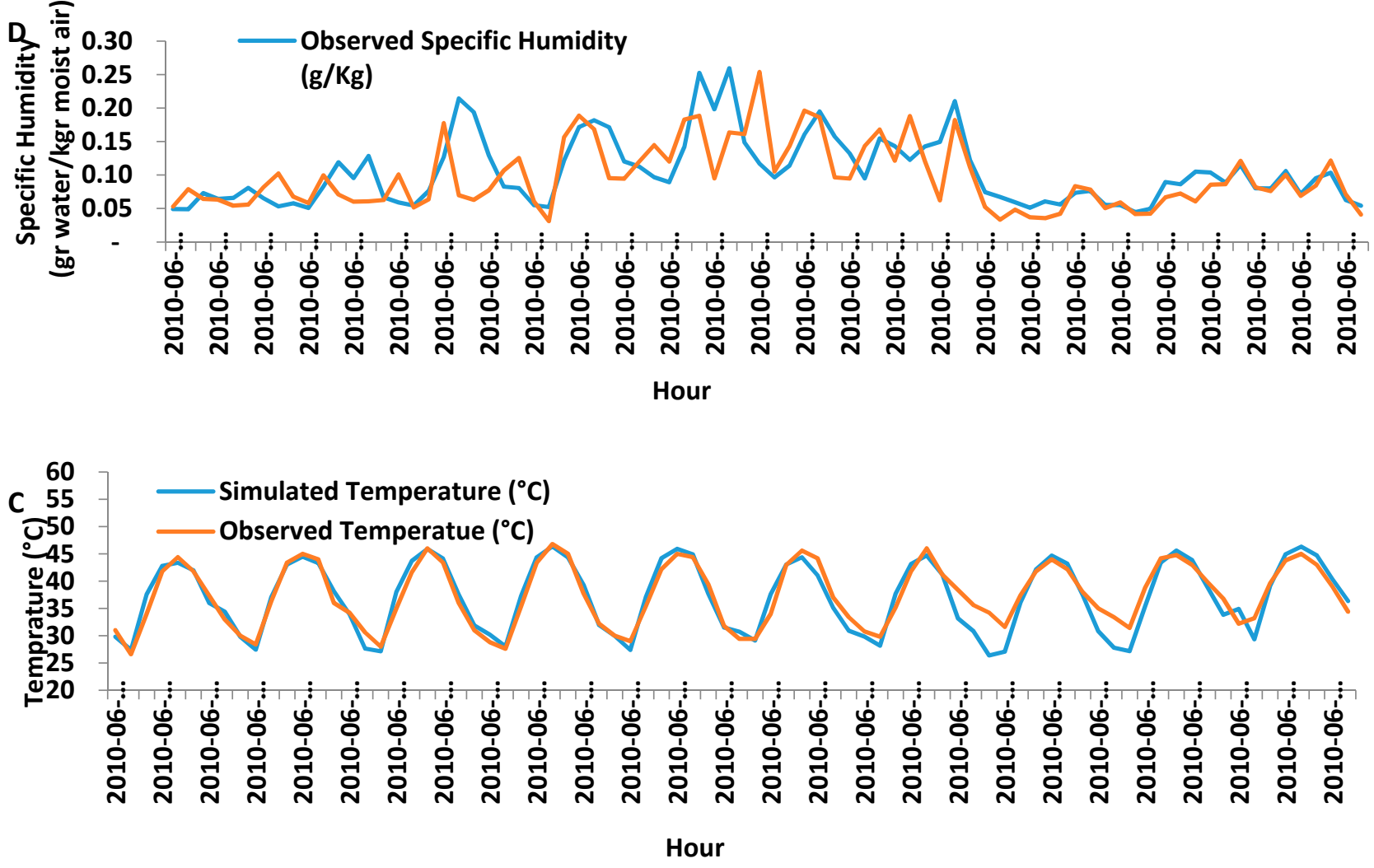

B
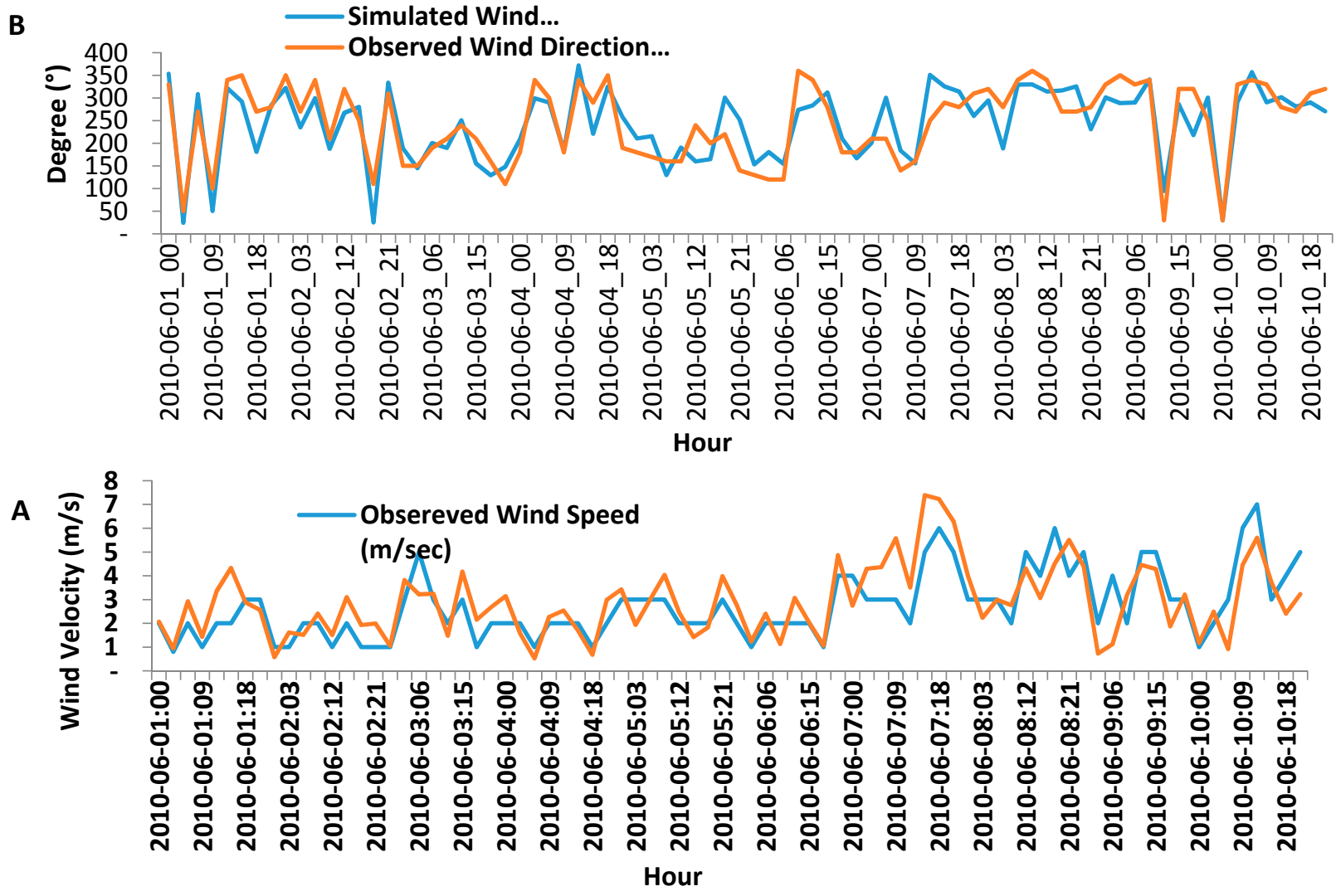

Fig. 3. The comparison of modeled and observed (A) Wind Speed, (B) Wind Direction, (C)

Temperature, (D) Humidity at sampling, Ahvaz city in Khozestan province, Iran between 6/1/2010

and 6/10/2010. 


\section{0 of 18}

The correlation coefficient between observed and simulated PM10 concentrations is $0.69(\mathrm{~N}=72)$, respectively. Fig. 6 illustrated the evolutionary pattern of surface PM10. This dust storm was caused by a cyclone on 7 June 2010 over arid and semi- arid regions in Syria and Iraq, and then transported to broad downwind regions including Khuzestan province in Iran especially Ahvaz city. Fig. 7 is illustration of the temporal distribution of simulated mineral dust concentration (ppm) for first, second, third, fourth and fifth bins (with $0.73,1.4,2.4,4.5$ and $8 \mu \mathrm{m}$ effective radius respectively, from June $6^{\text {th }}$ to June $9^{\text {th }} 2010$ at Daneshgah station, Ahvaz city. The most near surface concentrations and dust emission flux occurred over fourth bin with effective radius equal to 4.5 $\mu \mathrm{m}$. But fifth bin (sand distribution) with effective radius equal to $8.0 \mu \mathrm{m}$ showed the least dust emission flux and near surface concentration over Ahvaz city during studied period.
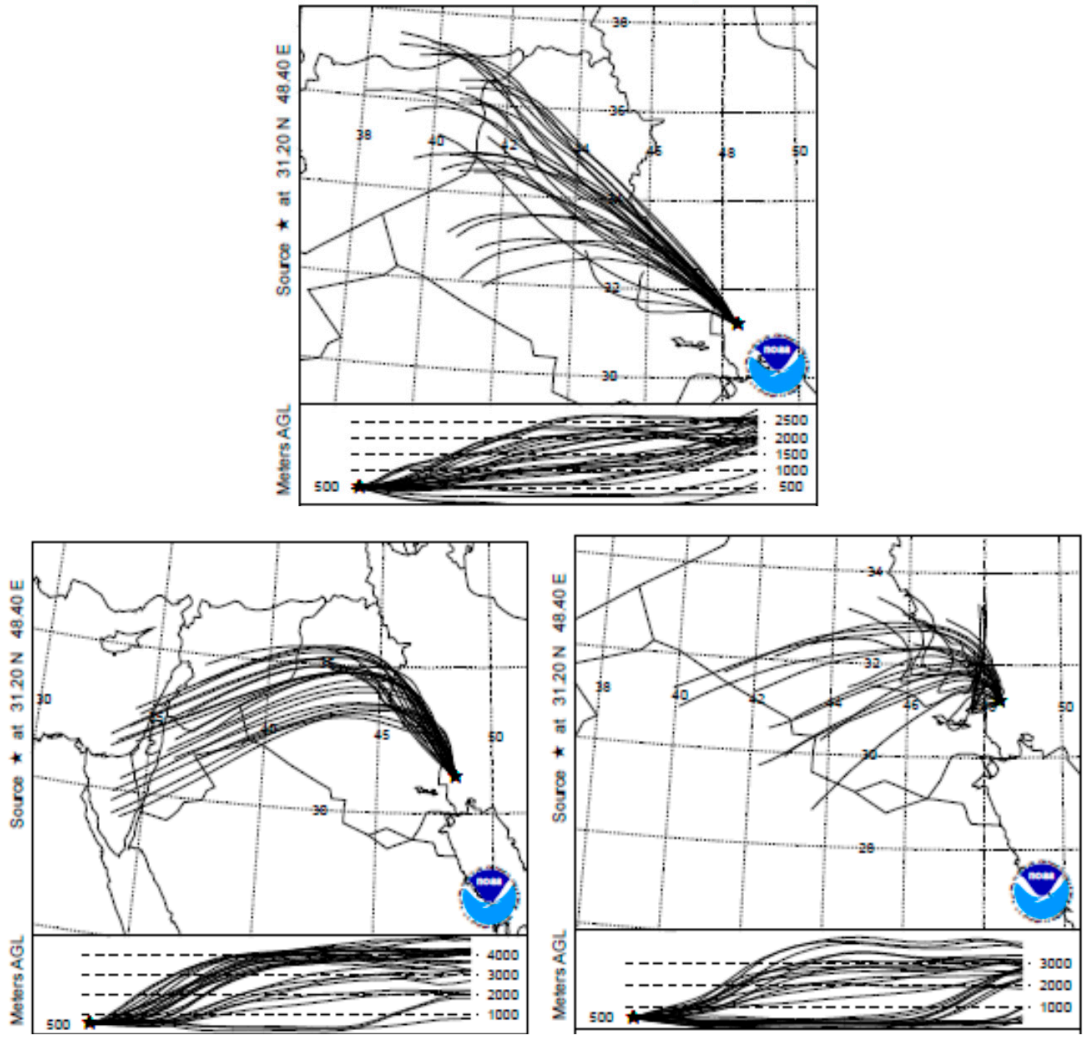

Fig. 4. HYSPLIT Back trajectory simulation, Ahvaz on (Left to Right) June $7^{\text {th }}$ June $8^{\text {th }}$, and June $9^{\text {th }}$ 2010.

\section{Discussion}

\subsection{Relationship between Dusty Days and Variation of Meteorological Parameters}

Any reduction in the amount of precipitation and relative humidity during warm period could lead to reduction in the top soil moisture content. The results indicated that season with the highest level of number of dusty days did not match the season with the highest maximum temperature, the minimum amount of rainfall and relative humidity. This result can confirm that the major sources of dust storms in Ahvaz city are neighboring countries. But the highest average prevail wind speeds were recorded in spring, which is in agreement with the season of the highest number of dusty days. As a result, a part of the dust storms over Ahvaz city have local sources [25, 28, and 29]. 


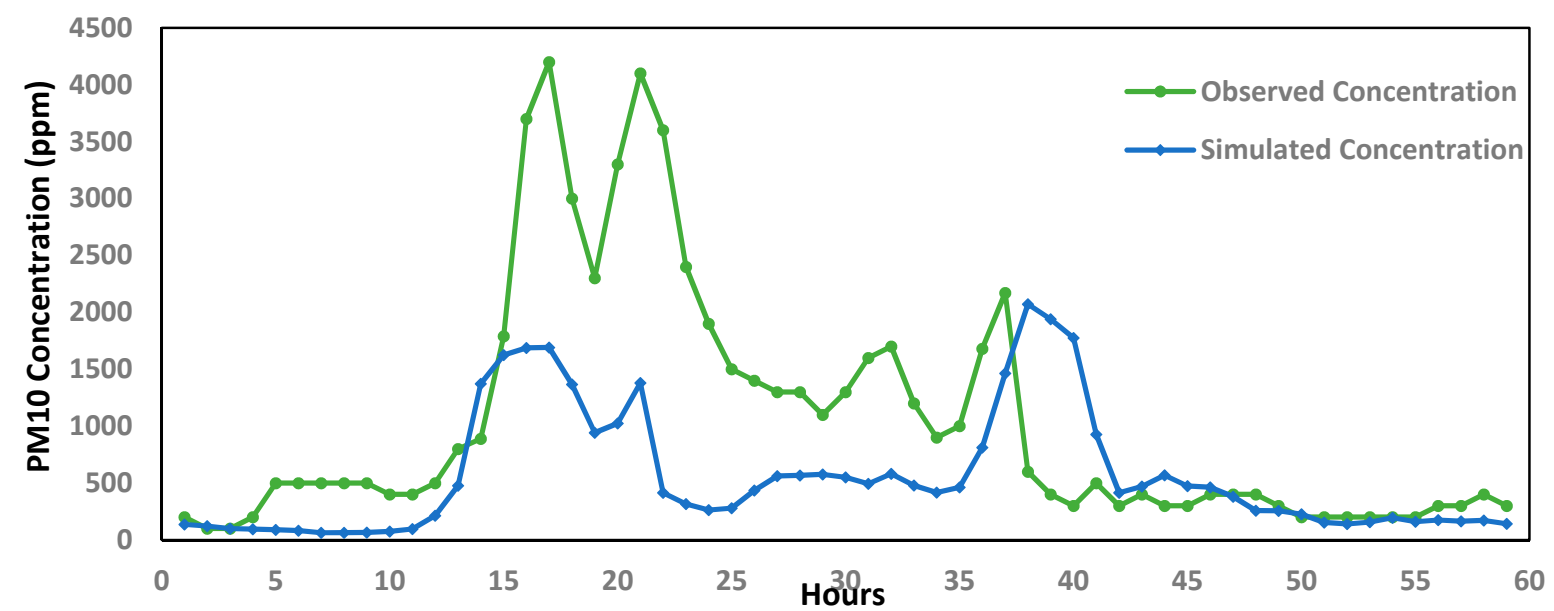

Fig. 5. The time series of observed hourly PM10 concentration and simulated hourly PM10 concentration from June $7^{\text {th }}$ to June $9^{\text {th }} 2010$ at Daneshgah station, Ahvaz city.

\subsection{Sources and Routes of Dust Storm with HYSPLIT}

Fig. 4 shows the dust particles has followed the same path from NW- SE to Ahvaz city. Which indicating Shamal winds is responsible for transporting dust particles from western parts of Iraq, eastern Syria and Jordan to Ahvaz city. Results of other studies [25, 30, 31, and 32] demonstrated the main dust resources over Iran are central to northern parts of Iraq, Eastern and central parts of Iraq and Syria, and northern parts of Saudi Arabia. The increase in the intensity of dust storms can be due to drought as well as adverse use of natural resources in Iran and in the neighboring countries specifically in Iraq. Iraq is one of the main origins of dust storms in Khuzestan province of Iran (especially Ahvaz city). Because of the dam projects by neighboring countries, the flow of the Euphrates and Tigris has a remarkable reduction. Iraq, Saudi Arabia, Jordan, Kuwait, southern part of Turkish and Syria which are located in the dust belt with arid and semiarid climate, known as principal sources of dust storms of Iran. Meanwhile, the Middle East is widely known for its frequent and intense dust and sand storms with its arid and semi-arid environment. Next to Africa, it is most affected by dust in the world, $[33,34]$. The intensity and frequency of dust storms have significantly increased in Iran during the last years. Which has put human health in danger in the southern provinces of Iran like the southwestern Khuzestan Province and northern part of southeastern Sistan and Baluchistan Provinces [35]. However, dust storms have serious impacts on the life of the people in these areas and have put even their breathing in trouble let alone with their work and other useful activities and the frequency intensity of these increasing dust storms and consequences have worried people. Also, this natural disasters can influence the rate of internal migration in these regions. The researchers found out that, on average, natural disasters like dust storms occurrence and drought can increase the number of migrants in the affected areas [36, 37]. They concluded that inter-provincial migration can be shaped by environmental changes as well as socio-demographic factors. The number of people engaging in international migration because of climate changes in compare with the number of people engaging in internal migration is small [37, 38]. But one outstanding argument is that climate change is able to affect the livelihood and 


\section{2 of 18}

of people in developing countries especially, result in an increase their motivations to migrate to countries. Saharan dust can be transported from its origin areas along three important transport paths ((a) westward over the North Atlantic Ocean to North America and South America, (b) northward across the Mediterranean to southern Europe and sometimes as far north as Scandinavia and (c) along easterly trajectories across the eastern Mediterranean to the Middle East [12]. It should be noted, that this crisis is spreading to the rest of the world even European countries. Over $70 \%$ of the increasing of the daily PM10 limit value in the most regional background (RB) sites of Spain have been assigned to dust outbreaks [39]. For the Eastern Mediterranean Basin, the same findings were received [40,41]. The regional background PM10 levels across the Mediterranean had increasing trends from the north to south and western to eastern of the Basin from 2000- 2007 [39].
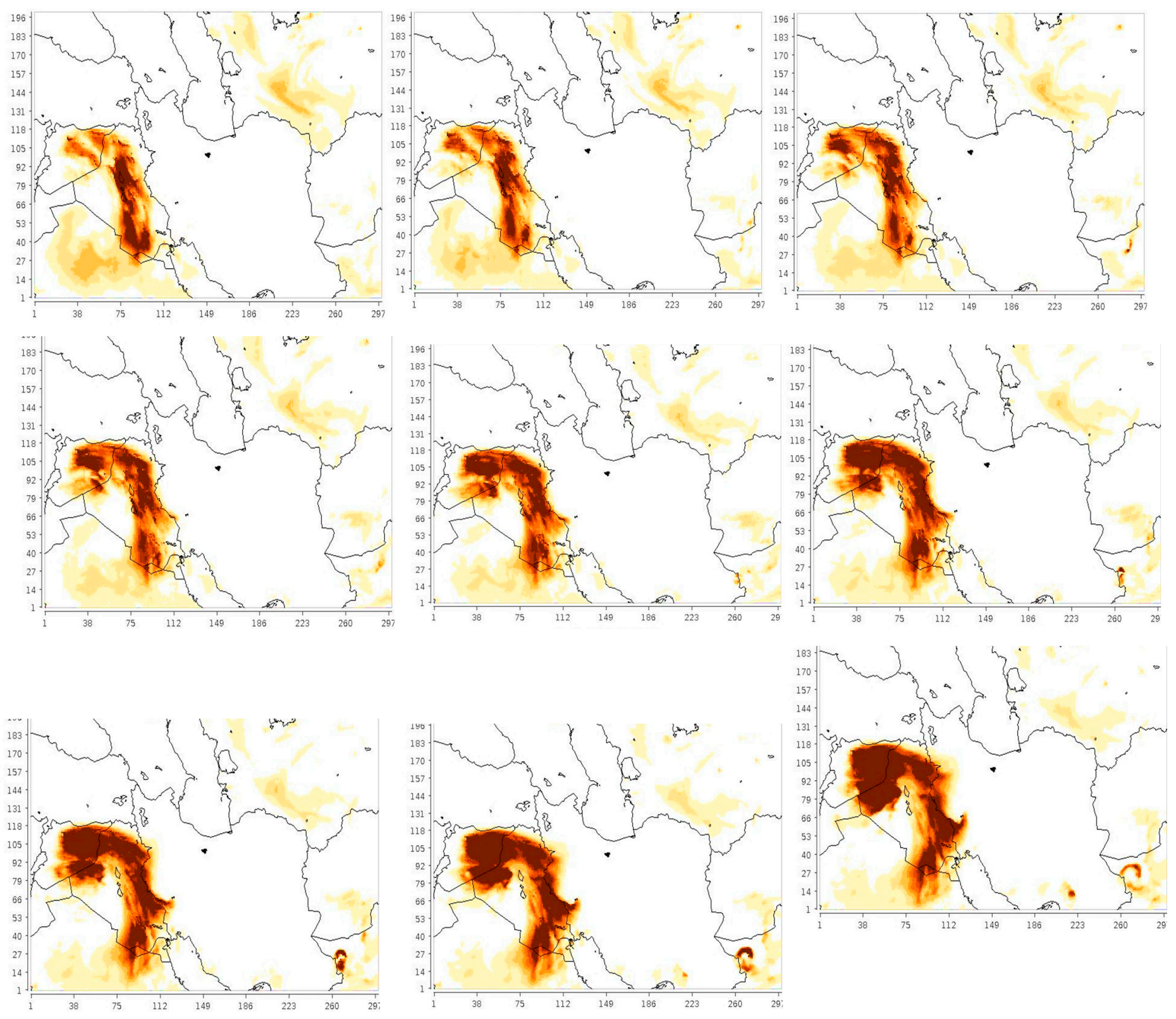

Fig. 6. The simulated spatial distribution of surface PM10 concentrations from June $7^{\text {th }}$ to June $9^{\text {th }}$ 2010 at Daneshgah station, Ahvaz city. 
As result, it is necessary to identify hotspots, measure their wind erosion capacity and take the effective and functional stabilizing methods of highly erodible regions immediately. Stopping flow of sand upwind (wind breaks and wind barriers, vegetation ...), stabilizing loose soil (vegetation, mulching ...) and surface binders (chemical coatings, watering ...) are different stabilizing methods which could be useful in reducing the vertical dust emissions. Future studies require focusing the effective techniques on the soil, topography, climate and vegetation cover properties of each hobtspiatulation of transport process and spatial distribution with WRF/Chem

The results show that the timing of maximum dust concentrations is simulated well, but there are some deviations in the peak magnitude and slight biases in the locations. The difference in positioning the peaks represented that the location of source or the strength of the source might not be well estimated. The underestimation of simulated PM10 concentrations might be because of underestimation of one of the source areas or deviation of meteorological fields during transportation which would cause the lower modeled PM10 concentration. According to the previous studies, there are some reasons lead to model uncertainty: (a) the values of friction velocity threshold, near surface moisture content for different types of soil, which are important parameters in initiation of dust deflation [42]; (b) meteorological fields during dust transportation [43]; (c) deficiency of model resolution in the source area [44]; and (d) strength of surface wind which is important in new considered generated origin areas with high dust concentrations during transportation [23, 43]. The considerable variations with observations are mainly because of using semi empirical "dust source functions" to parameterize dust emission proceedings $[45,46]$ in the available generation of dust modules. Regarding the impact of mineral dust, it is critical to use an accurate dust cycle in climatic and weather models. Therefore, the representation of dust cycle in weather and climate models needs an improvement. A physically based dust emission parameterization was represented by Kok, et al., (2014), which is straightforward to apply into the large scale models. This dust emission model is depending only on the wind friction velocity and threshold friction velocity of soil. A critical insight of the theory is that the dust flux is remarkably more sensitive to changes in the soil state than the most current climate models account for. As result further investigation are required to investigate the implementation of physically based parameterization, COMSALT, for the emitted vertical dust flux from an eroding soil to have an improvement in the representation of dust cycle in weather and climate models.

\section{Conclusion}

The most persistent and largest origins of dust storms are located in the Northern Hemisphere, remarkably in a broad "dust belt" which is extended from the west coast of North Africa, over the Middle East, Central and South Asia, to China. 


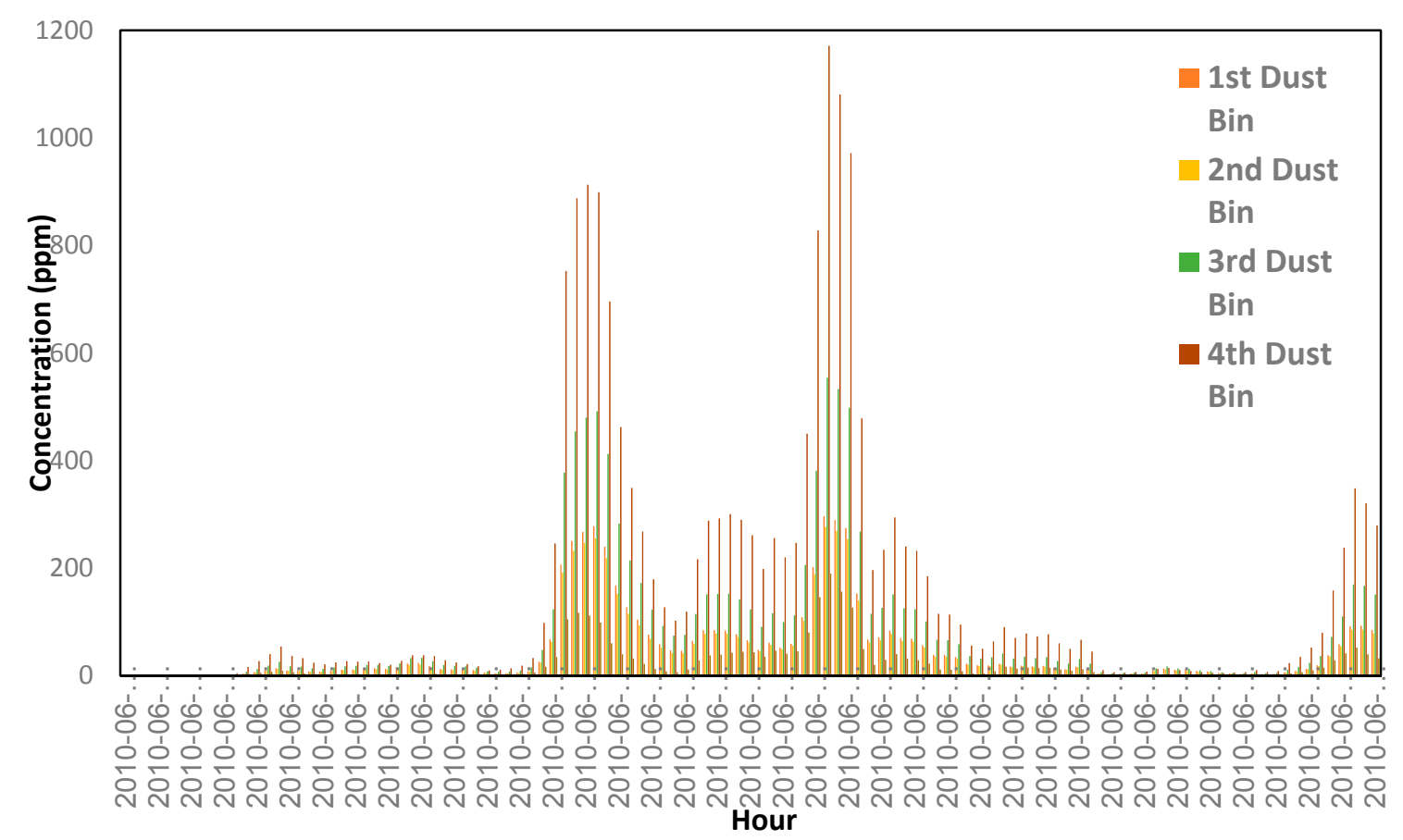

Fig. 7. Temporal distribution of simulated mineral dust concentration (ppm) for first, second, third, fourth and fifth bins (with $0.73,1.4,2.4,4.5$ and $8 \mu \mathrm{m}$ effective radius respectively, from June $6^{\text {th }}$ to June $9^{\text {th }} 2010$ at Daneshgah station, Ahvaz city.

Outside of this area, the dust activity is mostly not large- scale [48]. Nevertheless of strength or size of the dust origins, they can usually be associated with topographical lows located in arid areas annual rainfall under 200- $250 \mathrm{~mm}$. In this study, the relationship between meteorological parameters and the occurrence of dust storms in the city of Ahvaz was investigated and agreement between dust storm occurrences and prevail wind speed has been reported over the last 20 years. As a result the major source of dust storms over Ahvaz city are neighboring countries. We analyzed the long-range transport of a severe dust storm and its impact on the air quality of Ahvaz city from June $7^{\text {th }}$ to June $9^{\text {th }}$ 2010. During the transportation from source areas to downwind areas, dust particles could arrive at Ahvaz city in different directions: (a) NW- SE direction (the dust particles are transported from north western region of Iraq and eastern Syria), (b) W- E direction (the dust particles are transported from central parts of Iraq to the south western and western parts of Iran), which resulted in several peaks of PM10 concentrations. Dust particles, with local non- crustal emissions led to severe air pollution with maximum of PM10 reaching 4200 ppm. Also, the most near surface concentrations and dust emission flux occurred over fourth bin with effective radius equal to $4.5 \mu \mathrm{m}$. But fifth bin (sand distribution) with effective radius equal to $8.0 \mu \mathrm{m}$ showed the least dust emission flux and near surface concentration. Since the significant concentration of fifth bin can be seen only over sources regions specifically during dust storm formation. On other side, first bin with effective radius equal to $0.5 \mu \mathrm{m}$ which can play most mobility and with considerable concentration over long distance from its origins showed less fraction of concentration comparing with third and fourth bins with larger dust grains over Ahvaz city, which is because of being close Iraq, Saudi Arabia, Kuwait and some local western areas, where are main dust origins in this WRF/Chem model simulated the dust storm event on 7-9 June 2010 well in terms of temporal 
15 of 18

distribution and spatial evolution of dust aerosol, reflecting good capability in prediction of pollution during dust storm event. Therefore it can be taken as a reference in forecasting the daily quality.

\section{Acknowledgements}

The authors are most grateful to the relevant officials of Department of Environment, Iran, for providing the required data in this research.

\section{Author's contributions}

Parya Broomandi was the main investigator, collected the data, performed the analysis, and drafted the manuscripts. Bahram Dabir, Babak Bonakdarpour and Yousef Rashidi supervised the study. All authors read and approved the final manuscript.

\section{Competing interests}

The authors declare that they have no competing interests.

\section{References}

1. El-Askary, H.; Gautam, R.; Singh, R.; Kafatos, M. Dust storms detection over the Indo-Gangetic Basin using multi sensor data. Adv. Space Res., 2006, 37, pp. 728-733.

2. Dey, S.; Tripathi, S. N.; Singh, R. P.; Holben, B. N. Influence of dust storms on aerosol optical properties over the Indo-Gangetic basin. J. Geophys Res., 2004, 109.

3. Satheesh, S. K.; Moorthy, K.K. Radiative effects of natural aerosols. Atmos. Environ., 2005, 39, pp. 2089-211.

4. Kumar, K.; Barth, M.C.; Pfister, G.G.; Naja, M.; Brasseur, G.P. WRF-Chem simulations of a typical pre-monsoon dust storm in northern India: influences on aerosol optical properties and radiation budget. Atmos. Chem. Phys., 2014, 14, pp. 2431-2446.

5. Wang, K.; Zhang, Y.; Nenes, A.; Fountoukis, C. Implementation of dust emission and chemistry into the Community Multiscale Air Quality modeling system and initial application to an Asian dust storm episode. Atmos. Chem. Phys., 2012, 12.

6. Kalenderski, S.; Stenchikov, G.; Zhao, C. Modeling a typical winter-time dust event over the Arabian Peninsula and the Red Sea. Atmos. Chem. Phys., 2013, 13, pp. 1999-2014.

7. Teller, A.; Xue, L.; Levin, Z. The effects of mineral dust particles, aerosol regeneration and ice nucleation parameterizations on clouds and precipitation. Atmos. Chem. Phys., 2012, 12, pp. 9303-9320.

8. Zhao, C.; Liu, X.; Leung, L.; Hagos, S. Radiative impact of mineral dust on monsoon precipitation variability over West Africa. Atmos. Chem. Phys., 2011, 11, pp. 1879-1893. 
9. Li, F.; Ginoux, P.; Ramaswamy, V. Distribution, transport, and deposition of mineral dust in the Southern Ocean and Antarctica: Contribution of major sources. J. Geophys. Res., 2008, 113.

10. Prospero, J. M.; Landing, W. M.; Schulz, M. African dust deposition to Florida: Temporal and spatial variability and comparisons to models. J. Geophys. Res-Atmos., 2010, 115.

11. Huneeus, N.; Schulz, M.; Balkanski, Y.; Griesfeller, J.; Prospero, J.; Kinne, S.; Bauer, S.; Boucher, O.; Chin, M.; Dentener, F.; Diehl, T.; Easter, R.; Fillmore, D.; Ghan, S.; Ginoux, P.; Grini, A.; Horowitz, L.; Koch, D.; Krol, M. C.; Landing, W.; Liu, X.; Mahowald, N.; Miller, R.; Morcrette, J. J.; Myhre, G.; Penner, J.; Perlwitz, J.; Stier, P.; Takemura, T.; Zender, C. S. Global dust model intercomparison in AeroCom phase I. Atmos. Chem. Phys., 2011, 11, pp. 7781-7816.

12. Goudie, A.S.; Middleton, N.J. Saharan dust storms: nature and consequences. Earth Sci. Rev., 2001, 56, pp. 179-204.

13. Ashrafi, K.; Shafiepour-Motlagh, M.; Aslemand A.R.; Ghader, S. Dust storm simulation over Iran using HYSPLIT. J. Environ. Health Sci. Eng., 2014, 12:9.

14. Givehchi, R.; Arhami, M. Contribution of the Middle Eastern dust source areas to PM10 levels in urban receptors: Case study of Tehran, Iran. Atmos. Environ., 2013, 75, pp. 287-295.

15. Air quality guidelines: global update 2005, Particulate matter, ozone, nitrogen dioxide and sulfur dioxide. Copenhagen, WHO Regional Office for Europe, 2006.

16. IR.DOE data: Ahvaz air Pollution Monitoring Stations Datasets. Tehran, Iran: Department of Environment; 2016.

17. Draxler, R.R.; Hess, G. An overview of the HYSPLIT_4 modelling system for trajectories. Australian Meteorological Magazine., 1998, 47, pp. 295-308.

18. Jiang, F.; Liu, Q.; Huang, X.; Wang, T.; Zhuang, B.; Xie, M. Regional Modeling of Secondary Organic Aerosol over China Using WRF/Chem. J. Aerosol Sci., 2012, 43, pp. 57-73.

19. Koch, S.E.; Benjamin, S.G.; McGinley, J.A.; Brown, J.M.; Schultz, P.; Szoke, E.J.; Smirnova, T.G.; Shaw, B.L.; Birkenheuer, D.; Albers, S.; Peckham, S.E.; Grell, G.A. Real-Time Applications of the WRF Model at the Forecast Systems Laboratory, 84th AMS Annual Meeting, Seattle, USA, 2004.

20. Done, J.; Davis, C.A.; Weisman, M. the Next Generation of NWP: Explicit Forecasts of Convection Using the Weather Research and Forecasting (WRF) Model. Atmos. Sci. Lett., 2004, 5, pp. 110-117.

21. Ginoux, P.; Chin, M.; Tegen, I.; Prospero, J. M.; Holben, B.; Dubovik, O.; Lin, S. J. Sources and distributions of dust aerosols simulated with the GOCART model. J. Geophys Res-Atmos., 2001, 106, pp. 20255-20273. 
22. Grell, G.A.; Peckham, S.E.; Schmitz, R.; McKeen, S.A.; Frost, G.; Skamarock, W.C.; Eder, B. Fully Coupled "Online" Chemistry within the WRF Model. Atmos. Environ., 2005, 39, pp. 6957-6975.

23. Bian, H.; Tie, X.X.; Cao, J.J.; Ying, Z.M.; Han S.; Xue, Y. Analysis of a Severe Dust Storm Event over China: Application of the WRF-Dust Model. Aerosol Air Qualit. Res., 2011, 11, pp. 419-428.

24. Pielke, R.A., Mesoscale Meteorological Modeling. Academic Press, Orlando.1986.

25. Mehrabi, S.S.; Jafari, R. The relationship between climatic parameters and the occurrence of 278 dust (Case study:Khozestan province of Iran). J. water soil sci., 2015, 19:71, pp. 69-81. (In Persian)

26. Borge, R.; Alexandrov, V.; del Vas, J.J.; Lumbreras, J.; Rodriguez, E. A comprehensive sensitivity analysis of the WRF model for air quality applications over the Iberian Peninsula. Atmos. Environ., 2008, 42, pp. 8560-8574.

27. Carbonell, L.T.; Mastrapa, G.C.; Rodriguez, Y.F.; Escudero, L.E.; Gacita, M.S.; Morlot, A.B.; Montejo, I.B.; Ruiz, E.M.; Rivas, S.P. Assessment of the Weather Research and Forecasting model implementation in Cuba addressed to diagnostic air quality modeling. Atmos. Pollut. Res., 2013, 4, pp. 64-74.

28. Nastagdori, L.; Jugder, D.; Schung, Y. Analysis of dust storms observed. Mongolia during 1937-1999. Atmo. Environ., 2003, 37, pp. 1401-1411.

29. Abdovis, M.; Bahrami, H.; Darvishi, A. Correlation between climatic parameters with the occurrence of dust storms in Khuzestan province.2012. (Paper presented at First International Congress dealing with the phenomenon of dust and its harmful effects, Ahvaz). (In Persian)

30. Mofidi, A.; Jafari, J. Examining the role of regional atmospheric circulation on the Middle East in the summer dust storms in the South West of Iran. J. Arid Regions Geographic's Studies, 2011, 5, pp. 45-17. (InPersian)

31. Taghavi, F.; Owlad, E.; Safarrad, T.; Irannejad, P. Identifying and monitoring dust storm in the western part of Iran using remote sensing techniques. J. Earth Space Phys., 2013, 39: 3, pp. 83-96. (In Persian)

32. Zolfaghari, M.; Hashemi, M.N. Synoptic Survey and dynamic phenomenon fourteenth to the seventeenth of July 2008 dated dust Country. The second national conference of wind erosion and dust storms; Yazd University. 2011. (In Persian)

33. Kutiel, H.; Furman, H. Dust Storms in the Middle East: Sources of Origin and their Temporal Characteristics. Indoor Built Environ., 2003, 12, pp. 419-426.

34. Gerivani, H.; Lashkaripour, G.R.; Ghafoori, M.; Jafari, N. The source of dust storm in Iran: A case study based on geological information and rainfall data. Carpata. J. Earth Env.Sci., 2011, 6:1, pp. 297 - 308.

35. Misconi, H.; Navi, M. Medical Geology in the Middle East, Springer Netherlands, 2010, pp. 135-174.

36. Robalino, J.; Jimenez, J.; Chacon, A. the Effect of Hydro-Meteorological Emergencies on Internal Migration. World Development, 2014, 67, pp. 438-448. 
37. Waldinger, M. The Effects of Climate Change on Internal and International Migration: Implications for Developing Countries. Centre for Climate Change Economics and Policy Working Paper No. 217. 2015.

38. Piguet, E.; Pecoud, A.; Guchteneire, P. Migration and Climate Change: An overview. Refugee Surv. Quart., 2011, pp. 1-23.

39. Karanasiou, A.; Moreno, N.; Moreno, T.; Viana, M.; Leeuw, F.; Querol, X. Health effects from Sahara dust particles. ETC/ACM Technical Paper 2011/4. 2012.

40. Koçak M.; Mihalopoulos N.; Kubilay N. Contributions of natural sources to high PM10 and PM2.5 events in the eastern Mediterranean. Atmos. Environ., 2007, 41, pp. 3806-3818.

41. Mitsakou C.; Kallos G.; Papantoniou N.; Spyrou C.; Solomos S.; Astitha M.; Housiadas C. Saharan dust levels in Greece and received inhalation doses. Atmo.Chem. Phys., 2008, 8, pp. 11967-1996.

42. Han, Z.; Ueda, H.; Matsuda, K.; Zhang, R.; Arao, K.; Kanai, Y.; Hasome, H. Model Study on Particle Size Segregation and Deposition during Asian Dust Events in March 2002. J. Geophys. Res., 2004, 109.

43. Huang, X.X.; Wang, T.J.; Jiang, F.; Liao, J.B.; Cai, Y.F.; Yin, C.Q.; Zhu, J.L.; Han, Y. Studies on a Severe Dust Storm in East Asia and Its Impact on the Air Quality of Nanjing, China. Aerosol Air Qual. Res., 2013, 13, pp. 179-193.

44. Shaw, P. Application of Aerosol Speciation Data as an in Situ Dust Proxy Forvalidation of the Dust Regional Atmospheric Model (DREAM). Atmos. Environ., 2008, 42, pp. 7304-7309.

45. Cakmur, R.V.; Miller, R.L.; Perlwitz, J.; Geogdzhayev, I.V.; Ginoux, P.; Koch, D.; Kohfeld, K.E.; Tegen, I.; Zender, C. S. Constraining the magnitude of the global dust cycle by minimizing the difference between a model and observations, J. Geophys. Res-Atmos., 2006, 111.

46. Evan, A.T.; Flamant, C.; Fiedler, S.; Doherty, O. An analysis of aeolian dust in climate models. Geophys. Res. Lett., 2014, 41, pp. 5996-6001.

47. Kok, J.F.; Mahowald, N.M.; Fratini, G.; Gillies, J.A.; Ishizuka, M.; Leys, J.F.; Mikami, M.; Park, M.S.; Park, S.U.; Van Pelt, R.S.; Zobeck, T.M. An improved dust emission model- Part 1: Model description and comparison against measurements. Atmos. Chem. Phys., 2014, 14, pp. 13023-13041.

48. Prospero, J.M.; Ginoux, P.; Torres, O.; Nicholson, S.E.; Gill, T.E. Environmental characterization of global sources of atmospheric soil dust derived from the NIMBUS-7 Total Ozone Mapping Spectrometer (TOMS). Rev. Geophys., 2002, 10: 1029.

(C) 2016 by the authors; licensee Preprints, Basel, Switzerland. This article is an open access article distributed under the terms and conditions of the Creative Commons by Attribution (CC-BY) license (http://creativecommons.org/licenses/by/4.0/). 